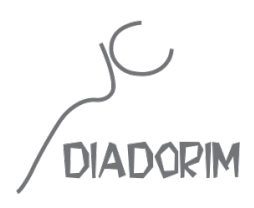

\title{
DEKODRÁ, O MELHOR BARBEIRO
}

\author{
Ana Paula Pacheco ${ }^{1}$
}

Depois que cientistas de várias partes do globo decretaram o fim de Odradek, surgiu a questão sobre os sucessores. Odradek não tinha filhos nem sobrinhos nem animais de estimação e permanecia vivíssimo como uma criança. Sem herdeiros ou metas que o desgastassem. Cálculos projetando os limites temporais de seu "organismo" mostraram-se um a um enganosos, sobretudo porque Odradek nunca teve uma tal natureza passível de ser designada por essa palavra. Os cientistas morriam, Odradek sobrevivia.

A notícia sobre seu fim era contudo indefectível. Circulou por grandes jornais, imprensa alternativa, Twiter, Instagram, Facebook, Whatsapp, Signal. Foi quando Odradek teve de se fingir de morto.

Um clone foi fabricado para não notarem sua falta. Idêntico em aparência ao original, apenas em aparência, assemelha-se a um carretel de linha achatado e esteliforme em cujo centro uma vareta transversal nasce e encontra outra em ângulo reto. Para em pé e move-se como se tivesse pernas. Na verdade tem pernas, mas depois de um treinamento circense consegue simplesmente aparentar ter pernas como se não as tivesse. Passa muito tempo sentado à escrivaninha.

Também esse legatário ou legatária — impossível ver seu sexo! — enrosca-se em fiapos multicoloridos um pouco sujos pela vida. A pobreza, que Odradek soube transformar em um bem porque não tem fome nem medo da polícia, é agora exibida pelo clone como uma qualidade para vencer na vida. Entre tantas possíveis, Dekodrá escolheu a vida universitária, por lhe parecer das mais épicas nos dias que correm.

1 Escritora. Universidade de São Paulo. E-mail: apsspacheco@gmail.com 
Com os colegas, porém, mal disfarça o embaraço. Difícil admitir, o mundo o constrange. Diante do espelho, deu-se conta disso: bastou atentar para o arco na coluna de pau, uma angulação côncava, o olhar voltado para baixo de modo a não encarar os inimigos; e se não fossem os fiapos a recobrirem tal sentimento jamais teria sido aprovado como o clone de Odradek. Toda leveza e imaginação descomprometida repousam naquele corpo tal qual uma âncora enferrujada.

Os cientistas consideraram a fisionomia de Dekodrá suficientemente apta para substituir o original. Tanto melhor que contradiga a si mesmo, ou melhor, ao outro; sinal dos tempos: cedo ou tarde tudo muda para pior. Mas olhos comuns não o veem assim. Convencidos pela gestualidade do clone, mal reparam nas diferenças. A produtividade tornou-se extensiva à luta pela falta de utilidade, os congressos nos quais se pronuncia mostrando ao mundo que não somos obrigados a aprender o idioma dos outros, um modo de combate mesmo nas férias. Ou nas "férias", talvez fosse apropriado dizer, porque sendo duplamente remuneradas — Dekodrá só viaja a trabalho - não há tempo para olhar pacificamente o céu, "ser, e mais nada", como gosta de dizer num suspiro.

Posso jurar, porém, que é mal compreendido por todos. A rigidez manifesta, enumerando equívocos, fazendo sofrer mesmo o mais animado com o próprio estudo - sobretudo o mais entusiasmado, pois o melhor barbeiro é o que sabe cortar asas - não é tão malévola quanto a saudade de uma existência menos penosa. Dekodrá sofre com a própria violência, embora não encontre outro modo de educar jovens e velhos hoje. Por isso está quase sempre furioso, quando não está comovido com o mais profundo afeto suscitado por um simples gesto de afago ou um elogio à sua capacidade intelectual.

Dekodrá vive alternadamente no gabinete subterrâneo da Universidade, nos corredores, no escritório anexo à lavanderia, onde a roupa suja se lava em casa. Às vezes desaparece por semanas, ocupado com algum trabalho bem pago nas faculdades privadas. No entanto, sempre volta. Quando perguntamos por onde andou, Dekodrá responde as piores coisas. A lição, posto que tácita, é clara - precisamos aprender com ele, em seus desvãos. Sem perguntas. São tempos difíceis.

Das ambivalências dos colegas nas mais bem intencionadas tentativas, sempre infere o pior. De boas intenções o inferno... ele ri, como quem tosse.

Muitos alimentam o secreto desejo de se livrarem desse ser compósito, como desejariam livrar-sede si mesmos - se fosse possível, cientificamente falando. Não obstante o caráter indigesto, Dekodrá é a última oportunidade de atualizarmos nossa inteligência. Por tal razão o suportamos.

Ultimamente, porém, triste como um gato que perdeu o dono, anda com cara de quem comeu e não gostou. Não sabemos bem como aconteceu, mas, desanimado, mudou de aparência 
e substância. "Passou de juvenil a senil antes de conhecer a maturidade", traduzem as más línguas. Vive repetindo que assim como um vento quente pode ser desagradável no verão, e mais ainda, pode trazer miasmas, influxos, energias letais, assim também a ideia de que Odradek possa retornar à vida e ultrapassá-lo lhe é dolorosa. Está inconsolável, e nos humilhar ou incentivar já não o renova. Por isso, como a uma criança que demora a largar a chupeta, procuramos consolá-lo oferecendo o dedo. 